Web Jurnal:

http://ejournal.kemenperin.go.id/jli

\title{
Utilization of mensiang (Actinoscorpus grosus L.) as a cellulose-rich material for furfural synthesis
}

\section{Peluang pemanfaatan mensiang (Actinoscirpus grosus L.) yang kaya selulosa sebagai bahan baku furfural}

\author{
Fransiska Angelina G Rezekinta*1, Anwar Kasim ${ }^{1}$, Novizar Nazir ${ }^{1}$, dan F. Failisnur ${ }^{2}$ \\ 1 Fakultas Pertanian, Universitas Andalas \\ Limau Manis, Padang, Sumatera Barat, Indonesia \\ 2 Balai Riset dan Standardisasi Industri Padang \\ Jl. Raya LIK No. 23 Ulu Gadut, Padang, Sumatera Barat, Indonesia \\ * e-mail: angelinarezekinta@gmail.com
}

\begin{tabular}{l}
\hline INFO ARTIKEL \\
\hline Sejarah artikel: \\
Diterima : \\
19 Agustus 2021 \\
Direvisi : \\
13 Desember 2021 \\
Diterbitkan : \\
30 desember 2021
\end{tabular}

\begin{tabular}{l}
\hline Keywords: \\
cellulose; \\
furfural; \\
mensiang
\end{tabular}

Kata kunci:

selulosa;

furfural;

mensiang

\begin{abstract}
The cellulose content of mensiang varies from $22 \%$ in the flower to $33 \%$ in the root. This could be used as a starting point for furfural synthesis. To separate furfural, several conditions are set for the distillation and evaporation processes. The conditions were rootstock part (A), upper stem part (B), whole stem part (C), whole stem with flowers part (D), and whole stem, flowers, and root part (E). Furfural content in the mensiang plant was conducted using Gas Chromatography-Mass Spectroscopy (GCMS) for the highest yield $11.78 \%$, D treatment. Furfural synthesized from the mensiang plant has a furfural content of $96 \%$. Furfural's density was $1.160 \mathrm{~g} / \mathrm{ml}$, boiling point was $161{ }^{\circ} \mathrm{C}$, refractive index was $1.5120^{\circ}$ brix, and its viscosity was $1.46 \mathrm{cp}$.
\end{abstract}

(C) 2021 Penulis. Dipublikasikan oleh Baristand Industri Padang. Akses terbuka dibawah lisensi CC BY-NC-SA

\section{Introduction}

Lignocellulosic biomass is a natural resource that is used for energy production or bioenergy. It is composed of three major elements: cellulose, hemicellulose, and lignin, as well as minor compounds (extractive substances) with low molecular weight, organic compounds, and ash as an inorganic compound (Phitsuwan et al., 2013). The most abundant and least expensive raw material on the planet is lignocellulosic biomass derived from agricultural and forest waste. Conversion of these materials into chemicals and other industrial products has become a concern in recent decades (Zhang et al., 2018).

Furfural is produced by hydrolyzing lignocellulosic biomass containing pentosan compounds and then dehydrating with inorganic/mineral acid catalysts such as sulfuric acid and hydrochloric acid. It's a clear, colorless or yellow liquid that smells like almonds but quickly turns yellow, brown, and black when exposed to air; and it's commonly referred to as furfuraldehyde (Gebre et al., 2015).

Indonesia is a tropical climate country that has abundant of lignocellulosic material. One of the 
lignocellulosic sources that we could easily find was Cyperaceae, a type of grass that is a herbaceous, grasslike plant found in wet areas all over the world. It has approximately 4,000 species and 70 genera (Butt et al., 2018). Actinoscirpus grossus, L. also known as mensiang or wlingi, is one of the many grass species found in Indonesia.

Mensiang grows abundantly in water or swamps, ponds, ditches, rice fields, and at an elevation of 900 meters above sea level. Mensiang is considered a weed in rice fields in Indonesia, where it can be controlled manually by plowing or with herbicides. It is commonly used to make mats or bags with a strong and durable texture that are also inexpensive. Mensiang post-harvest processing is done by taking the stalks, drying them in the sun, and then moving on to the next process for making products

Bagasse, corn cobs, and rice husks are common raw materials used to make furfural and contain pentosan at rates of $40.9 \%$ (Zhang et al., 2017), 32\% (Pressure, 2014), and $8.9 \%$ (Suxia et al., 2012), respectively. Bagasse and corn cobs are the most commonly used raw materials in furfural production, with more than $98 \%$ of all furfural production using corn cobs as raw materials supplied by China, the world's largest raw materials producer (Services, 2006). Some researchers, such as (Andaka, 2011), obtained a furfural yield of $5.67 \%$ using baggase, while (Coniwanti et al., 2016) obtained a furfural yield of $7.74 \%$ using a mixture of bagasse and coconut-shell.

In West Sumatra, common cellulose sources include rice husks (Helmiyati and Suci, 2019), hemp (Yulfa et al., 2019), corn cobs (Winarti et al., 2018), and water hyacinth (Asrofi et al., 2018). With a cellulose content of 36.21 percent (Bidin et al., 2015), Mensiang has the potential to become one of West Sumatra's sources of cellulose plants, one of which was used as a raw material in furfural production.

Mensiang containing 20-21.2\% pentosan (Brink and Escobin, 2016) could be used as a raw material for furfural production. Every part of the plant contains different chemical contents, as well as hemicellulose, which is the primary ingredient in the production of furfural. Cellulose, hemicellulose, and lignin are all components of cells, so the higher the hemicellulose content of plants, the closer to growth they are. Based on the description above, this study was conducted to determine the yield and quality of furfural produced by the conversion of mensiang plants.

\section{Method}

Mensiang (Actinoscirpus grossus, L.) (fig.1) were obtained from Aia Pacah in Padang and divided into lower stem, upper stem, flowers, and roots. The parts are then dried using a solar thermal method, cut into small pieces with a hammer mill, and sieved through an 60 mesh sieve before being placed in a ziplock plastic bag for further analysis. Sulfuric acid obtained from SMART-LAB as a catalyst, chloroform as an organic solvent, sodium chloride, and the materials used for chemical identification and analysis, which include furfural standard, analin, glacial acetic acid, and alcohol were obtained from MERCK, Germany, and distilled water are the chemicals used in the main process of furfural synthesis.

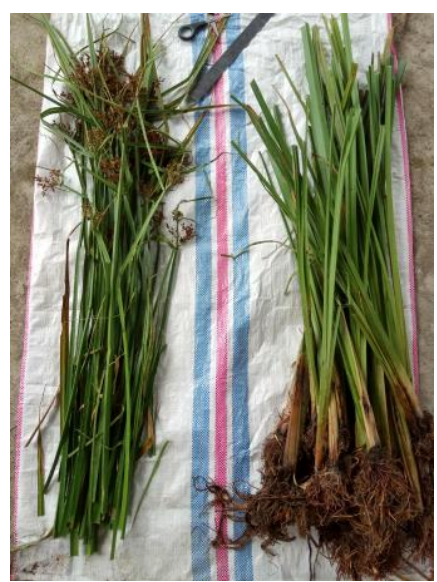

Figure 1. Washed mensiang

\subsection{Preparation of raw material}

Mensiang was prepared based on the treatment; rootstock (A), upper stem (B), whole stem (C), whole stem with flower (D), and whole stem, flowers, and root (E). From $128 \mathrm{~cm}$ height, Mensiang was separated into four part (flower, upper stem, rootstock, and root) and then prepared for the five treatments above. Mensiang was then dried and sieved through a 60 mesh sieve.

\subsection{Furfural synthesis}

$50 \mathrm{~g}$ of mensiang powder was prepared and placed in the distillation flask, along with $62.5 \mathrm{~g}$ of $\mathrm{NaCl}$ and 250 $\mathrm{ml}$ of $12 \% \mathrm{H}_{2} \mathrm{SO}_{4}$, while Erlenmeyer was filled with 50 $\mathrm{ml}$ chloroform. For two hours, the distillation was carried out at $120^{\circ} \mathrm{C}$. The distillate will be separated into two layers. The top layer is water, and the bottom layer is chloroform mixed with furfural, which is produced during the process. A separator was used to separate the chloroform from the water. The furfural was then separated from the chloroform using a vacuum evaporator set to $60-70^{\circ} \mathrm{C}$

\subsection{Characteristic analysis}

Raw materials and crude furfural were analyzed in this study. Raw material analysis included moisture content (Official methods of analysis of AOAC international 18th Ed, 2005), extractive substance content (TAPPI-T 280), holocellulose, cellulose (TAPPI-T 429), hemicellulose, and lignin (TAPPI, 2011) and for crude furfural was carried out on processing yield, determination of furfural content using GC-MS (Senila et al., 2013), identification of furfural using aniline acetate, density, refractive index, boiling point and furfural viscosity (Lomba et al., 2013).

\section{Result and discussion}

\subsection{Raw material composition}

The raw materials in this study were parts of the mensiang plant (Actinoscirpus grossus) including 
flowers, upper stem, rootstock, and roots. Analysis of the raw materials of the mensiang plant including extractive substances, cellulose, hemicellulose, and lignin content could be seen in Table 1 .

Table 1.

Analysis of mensiang plant raw materials

\begin{tabular}{lllll}
\hline \multirow{2}{*}{ Parameter } & \multicolumn{3}{c}{ Treatments $(\%)$} \\
\cline { 2 - 5 } & Extractive substances & Hemicellulose & Cellulose & Lignin \\
\hline Root part & $2.189 \pm 0.397$ & $27.945 \pm 0.714$ & $33.64 \pm 2.319$ & $34.28 \pm 4.299$ \\
Rootstock part & $5.305 \pm 1.85$ & $26.687 \pm 3.248$ & $32.63 \pm 1.357$ & $27.053 \pm 1.552$ \\
Upper stem part & $4.792 \pm 0.040$ & $23.993 \pm 0.372$ & $24.605 \pm 3.542$ & $28.669 \pm 3.601$ \\
Flower part & $9.355 \pm 4.348$ & $30.237 \pm 4.572$ & $22.46 \pm 1.584$ & $37.66 \pm 0.707$ \\
\hline
\end{tabular}

The raw material used has been dried and passes through a 60 mesh sieve. Extractive substances were found in $2.189 \%$ of the roots, $5.305 \%$ of the rootstock, $4.792 \%$ of the upper stem, and $9.335 \%$ of the flowers. Extractive substances are plant substances other than cellulose, hemicellulose, and lignin. Plants typically contain less than $10 \%$ extractive substances (Lukmandaru, 2011). Plant extractives, in general, dissolve easily in ether, alcohol, or water solvents. Extractive substances in plants can be used for wood identification because the extractive substances differed depending on the type of wood.

For roots, rootstocks, upper stem, and flowers, the cellulose content was $33.64 \%, 32.63 \%, 24.605 \%$, and $22.4 \%$, respectively. The cellulose content of the Mensiang plant is 36.21 percent (Bidin et al., 2015), but the results vary because they are from different parts of the plant. Cellulose in plants was useful in the formation of plant cell walls, and it was also widely used in the production of pulp and paper. The rootstock has a higher cellulose content than the upper stem. This is due to the fact that growth begins at the bottom of the stem. Cellulose content was found to be related to the formation of cell walls, which is consistent with plant growth.

The hemicellulose content (Glucuronoxylan) of the dry weight of wood generally ranges from $15-30 \%$ (Rowell et al., 2021). In this study, the root hemicellulose yield was $27.945 \%$, the rootstock yield was $26.687 \%$, the upper stem yield was $23.993 \%$, and the flower yield was $30.237 \%$. The presence of hemicellulose in raw materials was critical because pentosan, a component of hemicellulose, was required for the production of furfural. Hemicellulose is made up of various sugar monomers.

The difference in raw material component content was caused by the location of these components in the plant. In plants, cellulose was a component of the cell wall. Cellulose, a glucose homopolymer with no branches, stiffens the plant cell walls. Cellulose, hemicellulose, pectin, and protein form a network that strengthens plant cell walls, making cellulose difficult to isolate (Rowell et al., 2021). Hemicellulose is made up of sugar and modified sugar heteropolymers that are bonded together with cellulose to strengthen the secondary cell wall (Zhang et al., 2015).

According to Brink \& Escobin (2016), mensiang contained $21.2 \%$ pentosan, whereas (Bidin et al., 2015) states that it has $49.88 \%$ hemicellulose. Because raw material determination was carried out for parts of the mensiang plant, the results obtained differ from those obtained by previous researchers.

\subsection{Furfural yield}

The yield of furfural could be seen in Table 2. The highest yield was obtained in treatments $\mathrm{C}$ and $\mathrm{D}$ with a yield of $11.78 \%$, while the lowest yield was obtained in treatment $\mathrm{E}$ with a yield of $5.76 \%$. The results differed from those obtained in previous studies, such as (Wang et al., 2018), which obtained $65.67 \%$ furfural yield with corn cob as raw material, and (Andaka, 2011) which obtained $5.67 \%$ furfural yield with bagasse as raw material at a reaction time of 120 minutes. (Hambali et al., 2016) obtained a furfural yield of $1.87 \%$ from rice husk. Because of differences in the raw materials used, the results obtained varied. According to the research, different parts of the mensiang plant contain different amounts of hemicellulose. The higher the hemicellulose content of the material, the closer it is to the point of growth. According to the results, the rootstock and upper stem produced the highest yield.

Table 2.

Furfural Yield on Different Plant Parts of Mensiang

\begin{tabular}{lc}
\hline Treatments & Yield $(\%) \pm$ Standard Deviation \\
\hline A & $9.97 \pm 0.40$ \\
B & $8.75 \pm 0.31$ \\
C & $11.78 \pm 0.92$ \\
D & $11.78 \pm 0.35$ \\
E & $5.76 \pm 0.70$ \\
\hline
\end{tabular}

However, due to the saponification process that occurs during the distillation process, treatment $\mathrm{E}$ had the lowest yield of $5.76 \%$. Because each part of the plant contains hemicellulose, the combination of parts of the mensiang plant was expected to yield the highest yield. Saponification was a reaction between fats (fatty acids or glycerol) and alkaline substances The root part of the plant was used in treatment E, where the root part of the plant contained a tuber. Triterpenoids are found in the tubers of mensiang plants, where triterpenoids were constituents of saponin compounds (Triterpenoid saponins) (Zhao and $\mathrm{Li}, 2018$ ), which are thought to cause the saponification process during the distillation process (Ganapathi et al., 2017). 


\subsection{Furfural content}

The furfural content in the sample was determined using Gas Chromatograph - Mass Spectrophotoscopy (GC-MS). Fig. 2 showed the results of the furfural content. According to the chromatogram of the crude furfural sample, 7 peaks were read in the data analysis, with retention times of $1.143 ; 1.190 ; 1.303 ; 1.585$; 3.193; 5.235; and 5.981. The furfural compound was read at a retention time of 3.193 seconds and a concentration of $96.23 \%$. The result for the furfural content in sample was read around the same peak as the standar furfural for the retention time 3.114 seconds and concentration $92.10 \%$.

Table 3.

Chemical content of furfural samples

\begin{tabular}{lllll}
\hline Peak & $\begin{array}{l}\text { Retention time } \\
(\mathrm{min})\end{array}$ & $\begin{array}{l}\text { Concentration } \\
(\%)\end{array}$ & $\begin{array}{l}\text { Molecular weight } \\
(\mathrm{Mol})\end{array}$ & Compound name \\
\hline 1 & 1.143 & 0.41 & 46 & Ethanol \\
2 & 1.190 & 0.17 & 46 & Formic Acid \\
3 & 1.303 & 0.26 & 60 & Acetic Acid \\
4 & 1.585 & 0.36 & 179 & Pyrolidine,1-(6-Ethil-1-Cyclohexan-1-Yl) \\
5 & 3.193 & 96.23 & 96 & Furfural \\
6 & 5.235 & 0.61 & 98 & 2(5H)-Furanone,5-Methyl \\
7 & 5.981 & 1.91 & 110 & 2-Furanocarboxaldehyde \\
\hline
\end{tabular}
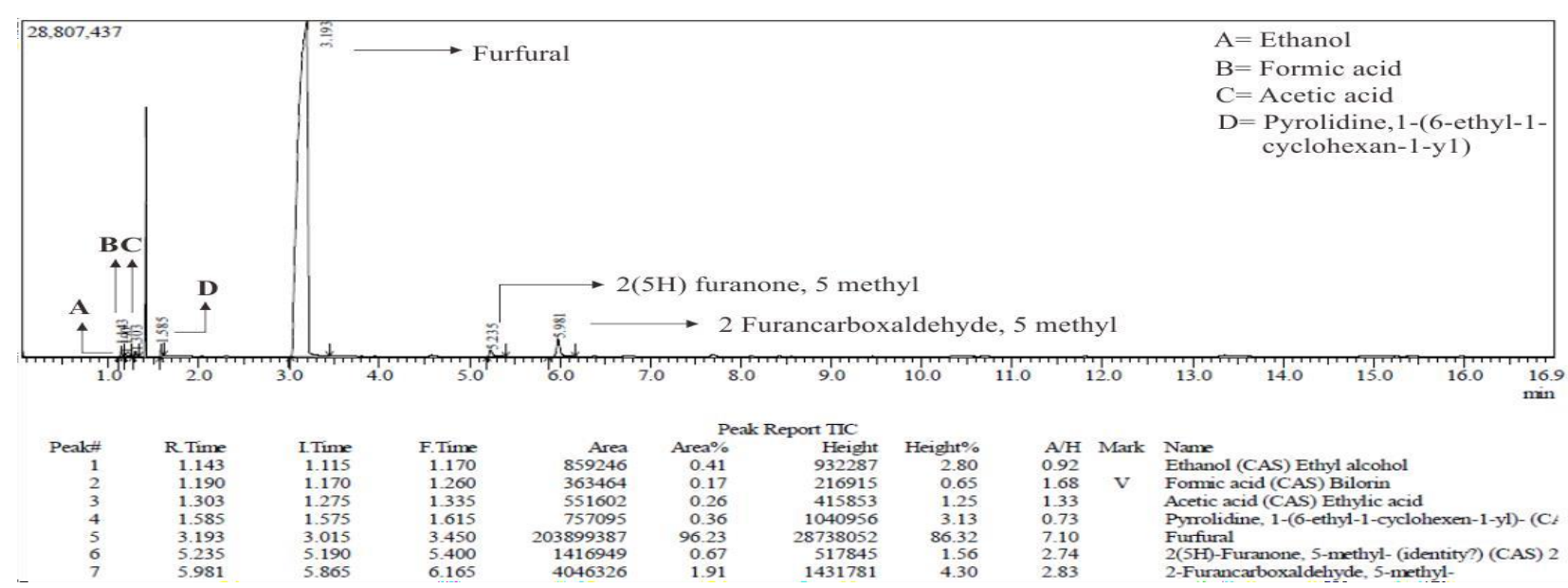

Figure 2. Furfural Sample Solution Chromatogram

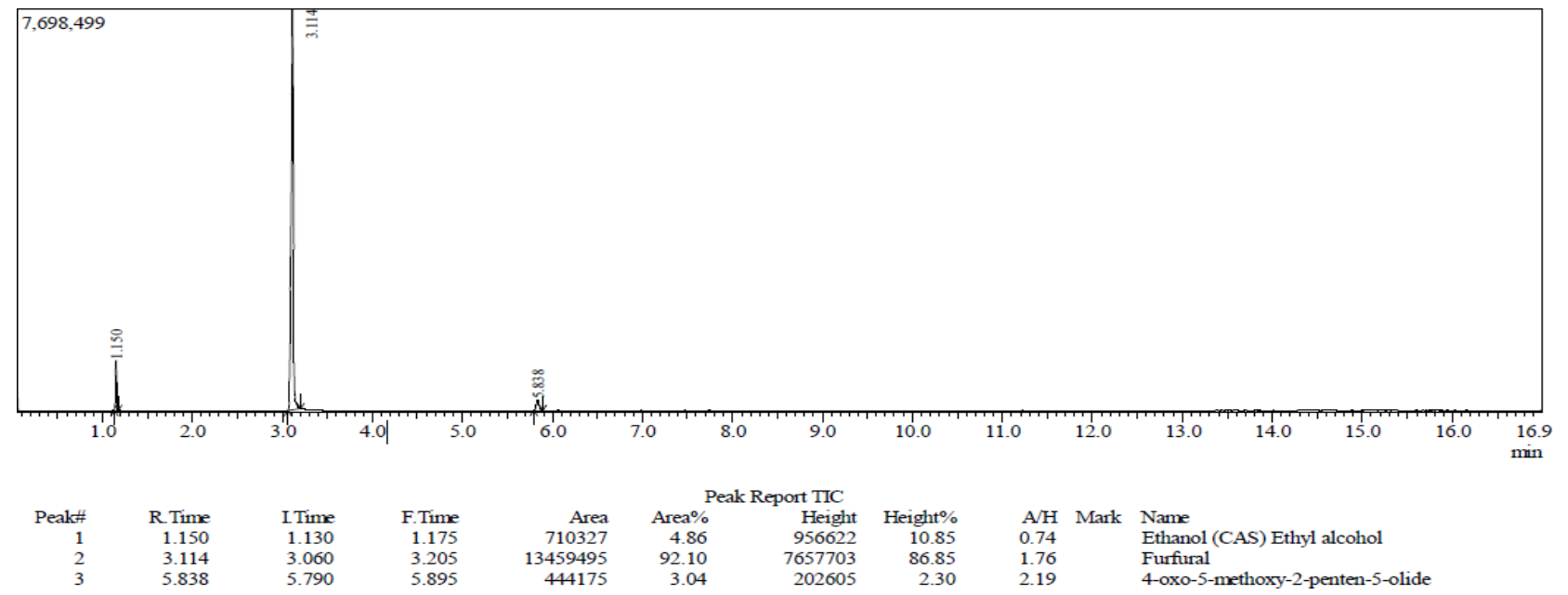

Figure 3. Furfural standard solution chromatogram

According to (Farmakope Indonesia Edisi V., 2014), the retention time difference between the test result chromatogram and the comparison chromatogram is typically less than a tenth of a minute. The probability of correct identification is quite high if the peaks have the same time under the same conditions.

The furfural sample has a higher concentration than the analyzed standard furfural solution. Table 3 contains additional data from observations. There are several non- 
furfural compounds detected, which may result in some differences in the observations of furfural properties. A reactive distillation could be used as a method to overcomes some disadvantages as for lack in purity and results in a higher yield of furfural (Metkar et al., 2015).

Tabel 4.

Properties of furfural

\begin{tabular}{lllll}
\hline Treatment & Density $(\mathrm{g} / \mathrm{ml})$ & Boiling Point $\left({ }^{\circ} \mathrm{C}\right)$ & Refractive index $\left({ }^{\circ}\right.$ brix $)$ & Viscosity $(\mathrm{cp})$ \\
\hline A & 1.140 & 161 & 1.512 & 1.29 \\
B & 1.130 & 160 & 1.502 & 1.46 \\
C & 1.153 & 1154.5 & 1.497 & 1.30 \\
D & 1.147 & 159 & 1.506 & 1.31 \\
E & 1.160 & 159 & 1.501 & 1.35 \\
\hline
\end{tabular}

\subsection{Aniline acetate for furfural identification}

To determine the results obtained were furfural, furfural identification with aniline acetate was performed. The sample is tested by sprinkling an aniline:acetate $(1: 1)$ solution on it. Table 5 shows the results of furfural identification with aniline acetate.

Table 5.

Identification of furfural using aniline acetate

\begin{tabular}{llll}
\hline \multirow{2}{*}{ Treatments } & \multicolumn{2}{c}{ Aniline acetate identification } \\
\cline { 2 - 4 } & & Colour & result \\
\hline A & 2 & Dark red & + \\
B & 2 & Dark red & + \\
C & 2 & Dark red & + \\
D & 2 & Dark red & + \\
E & 2 & Dark red & + \\
\hline
\end{tabular}

(+) contains furfural

Based on the observations, each furfural sample tested produced a red color when reacted with aniline acetate, as shown in Table 5. This demonstrates that all of the samples obtained were furfural. A condensation reaction between furfural and aniline produces dianil hydroxy gluconate dialdehyde, which causes the color to change to dark red.

Furthermore, (Pressure, 2014) describes the reaction that occurs when aniline acetate is reacted with furfural. The reaction occurs in two stages. The first stage involves the formation of a yellow color, which then reacts with aniline, resulting in the breakdown of the furfural ring to form dialdehyde. This reaction was used as a furfural test because furfural has chemical properties that cause a distinct color when reacted with aniline.

\subsection{Density of furfural}

The furfural density from parts of the mensiang plant can be seen in Table 4. Furfural density ranges from $1.155 \mathrm{~g} / \mathrm{ml}$ to $1.161 \mathrm{~g} / \mathrm{ml}$ at $20^{\circ} \mathrm{C}$, according to (States and Toxicology, 1989). According to Table 4, the furfural densities obtained ranged from $1.130 \mathrm{~g} / \mathrm{ml}$ to $1.160 \mathrm{~g} / \mathrm{ml}$. Densities included in standards are $1.153^{\circ} \mathrm{C}$ for treatment $\mathrm{C}$ and $1.160^{\circ} \mathrm{C}$ for treatment $\mathrm{E}$. The density of the plant parts differs slightly, as shown in table 4 . This is influenced by the mass of wood at the base, which is dominated by latewood with thick cell walls and small cell cavities, resulting in a higher density. This influences the density of plant parts from the plant's base to the plant's tip (flowers) (Uar et al., 2018).

\subsection{Boiling point}

More than $95 \%$ of furfural is distilled at temperatures ranging from $159^{\circ} \mathrm{C}$ to $162^{\circ} \mathrm{C}$, according to (Farmakope Indonesia Edisi V., 2014). According to Table 4, the furfural boiling point ranges from $154^{\circ} \mathrm{C}$ to $161^{\circ} \mathrm{C}$, so the average furfural boiling point of the research results was still within the predetermined range. Furfural has a boiling point of $161^{\circ} \mathrm{C}$, according to (Gebre et al., 2015).

The boiling point of furfural is affected by the density of furfural, plant part that has higher density affected the boiling point of the furfural. Table 4 shows that the higher the density, the lower the boiling point (Gao et al., 2017).

Treatment $\mathrm{C}$ had a boiling point of $154.5^{\circ} \mathrm{C}$, which was lower than Pharmacopeia and Barenbers standards. When making observations, the air pressure caused this. A difference in pressure can cause a difference in the boiling points of a solution. When the pressure in a pressure chamber varies slightly from $760 \mathrm{mmHg}$, the boiling point of the organic liquid deviates from the specified value (Firdaus, 2011).

\subsection{Refractive Index}

Based on (Mitarlis et al., 2011), the refractive index of furfural at $20^{\circ} \mathrm{C}$ was $1.5261{ }^{\circ}$ Brix and at $25{ }^{\circ} \mathrm{C}$ was $1.5235^{\circ}$ brix. According to Table 4, the furfural sample obtained has a refractive index value lower than the standard, with the highest refractive index obtained in treatment $\mathrm{A}$ at $20.4^{\circ} \mathrm{C}$ being $1.5120^{\circ}$ brix. This is due to the presence of substances other than furfural in the samples under investigation. GC-MS analysis revealed that the samples obtained contained compounds other than furfural, such as formic acid, ethanol, acetic acid, and pyrrolidine. These compounds can cause the sample's refractive index reading to differ from the literature.

Firdaus (2011) stated that a compound's refractive index is extremely sensitive to the presence of impurities. Aside from the hemicelllulose used in furfural synthesis, different plant parts contain a variety of chemical compounds. In particular, chlorophyll in the plant's stem and other companies. Meanwhile, those compounds were removed during the distillation process. 
We can see from the table that the refractive index of the furfural is mostly the same.

\subsection{Viscosity}

Furfural viscosity was 1.36 mpa.s-1, according to (Lomba et al., 2011) Meanwhile, the furfural viscosity observations obtained did not meet the existing literature value. According to Table 4, treatment $B$ had the highest furfural viscosity $(1.46 \mathrm{cp})$, while treatment $\mathrm{A}$ had the lowest $(1.29 \mathrm{cp})$. This is due to the presence of other compounds in the sample besides furfural. GC-MS observations revealed that there were other compounds in the sample besides furfural. According to (Lide and Baysinger, 2005), the formic acid compound has a viscosity of 1.607 mpa.s-1, which was thought to affect the furfural viscosity tested.

The viscosity of the furfural will be affected by the part of the plant with a higher boiling point. Furfural has a high mobility because of its high boiling point. As a result, the viscosity of furfural decreases. Table 4 shows that the sample with the highest boiling point has the lowest viscosity.

\section{Conclusion}

Following the research findings, mensiang plant can be used as a source of cellulose, with cellulose content ranging from 22 to $33 \%$ in parts of the plant, and it can also be used as a raw material for furfural production, with the highest yield of $11,78 \%$ in treatments $C$ and D. The results also revealed that the obtained furfural content is $96 \%$ higher than the commercial furfural standard, whereas the commercial furfural standard has $92,10 \%$. More research should be done on the saponification that occurs during the distillation process in order to increase the furfural yield.

\section{References}

Andaka, G., 2011. Hidrolisis ampas tebu menjadi furfural dengan katalisator asam sulfat. J. Teknol. 4, 180-188.

Asrofi, M., Abral, H., Kasim, A., Pratoto, A., Mahardika, M., Hafizulhaq, F., 2018. Mechanical properties of a water hyacinth nanofiber cellulose reinforced thermoplastic starch bionanocomposite: Effect of ultrasonic vibration during processing. Fibers 6, 1-9. https://doi.org/10.3390/fib6020040

Bidin, N., Zakaria, M.H., Bujang, J.S., Aznadia, N., Aziz, A., 2015. Suitability of aquatic plant fibers for handmade papermaking 2015.

Brink, M., Escobin, R.., 2016. Plant resource of south east asia-fiber plants. Backhuys Publisher: Leiden., p. 453.

Butt, M.A., Zafar, M., Ahmad, M., Sultana, S., Ullah, F., Jan, G., Irfan, A., Naqvi, S.A.Z., 2018. Morphopalynological study of Cyperaceae from wetlands of Azad Jammu and Kashmir using SEM and LM. Microsc. Res. Tech. 81, 458-468. https://doi.org/ 10.1002/jemt.22999

Coniwanti, P., H, G.S., Handayani, E., 2016. Pembuatan furfural dari campuran biomassa ampas tebu
(Saccharum officinarum L.) dan tempurung kelapa (Cocos nucifera L.) 22, 37-45.

Farmakope Indonesia Edisi V., 2014. . Kementrian Kesehatan RI.

Firdaus, 2011. Teknik dalam laboratorium kimia organik. Program Studi Kimia, Jurusan Kimia, Fakultas Matematika dan Ilmu Pengetahuan Alam, Universitas Hasanuddin.

Ganapathi, S.C., Holla, R., Shankara, S., Narayana, S.K.K., Mundugaru, R., 2017. Microscopical evaluation, phytochemical analysis and HPTLC fingerprinting of tuber of actinoscirpus grossus (L.f.) goetgh. \& d.A.Simpson. Pharmacogn. J. 9, 657-662. https://doi.org/10.5530/pj.2017.5.104

Gao, H., Idem, R., Liang, Z., Tontiwachwuthikul, P., 2017. Density, viscosity, refractive index and heat capacity studies of aqueous ethylaminoethanol solutions at 293.15 to $323.15 \mathrm{~K}$. Energy Procedia 114, 1523-1529. https://doi.org/10.1016/ j.egypro.2017.03.1279

Gebre, H., Fisha, K., Kindeya, T., Gebremichal, T., 2015. Synthesis of furfural from bagasse. Int. Lett. Chem. Phys. Astron. 57, 72-84. https://doi.org/ 10.18052/www.scipress.com/ilcpa.57.72

Hambali, M., Novriyanti, R., Anytia, S.D., 2016. Pemanfaatan limbah sekam padi untuk pembuatan furfural dengan variasi katalisator asam sulfat dan asam klorida. J. Tek. Kim. 22, 53-61.

Helmiyati, H., Suci, R.P., 2019. Nanocomposite of cellulose- $\mathrm{ZnO} / \mathrm{SiO} 2$ as catalyst biodiesel methyl ester from virgin coconut oil. AIP Conf. Proc. 2168. https://doi.org/10.1063/1.5132490

Lide, D.R., Baysinger, G., 2005. CRC handbook of chemistry and physics. CRC Press, Boca Raton.

Lomba, L., Giner, B., Bandr, I., 2011. Green chemistry physicochemical properties of green solvents derived from biomass $\dagger$ 2062-2070. https://doi.org/10.1039/c0gc00853b

Lomba, L., Giner, B., Carmen, M., Aldea, L., Lafuente, C., 2013. Thermophysical properties of furfural compounds. J. Chem. Eng. Data.

Lukmandaru, G., 2011. Variability in the natural termite resistance of plantation teak wood and its relations with wood extractive content and color properties. Indones. J. For. Res. 8, 17-31. https://doi.org/ 10.20886/ijfr.2011.8.1.17-31

Metkar, P.S., Till, E.J., Corbin, D.R., Pereira, C.J., Hutchenson, K.W., Sengupta, S.K., 2015. Reactive distillation process for the production of furfural using solid acid catalysts. Green Chem. 17, 14531466. https://doi.org/10.1039/c4gc01912a

Mitarlis, Ismono, Tukiran, 2011. Pengembangan metode sintesis furfural berbahan dasar campuran limbah pertanian dalam rangka mewujudkan prinsip green chemistry. J. Mns. dan Lingkung. 18, 191-199.

Official methods of analysis of AOAC international 18th Ed, 2005. AOAC International, Gaithersburg, MD, USA, Of fi cial Method 2005.08.

Phitsuwan, P., Sakka, K., Ratanakhanokchai, K., 2013. Improvement of lignocellulosic biomass in planta: A review of feedstocks, biomass recalcitrance, and strategic manipulation of ideal plants designed for ethanol production and processability. Biomass and 
Bioenergy 58, 390-405. https://doi.org/ 10.1016/j.biombioe.2013.08.027

Pressure, A., 2014. Production of furfural from corncobs agricultural waste by acid hydrolysis at atmospheric pressure. J. Bahan Alam Terbarukan 3, 71-75. https://doi.org/10.15294/jbat.v3i2.5765

Rowell, R.M., Rowell, R.M., Pettersen, R., Tshabalala, M.A., 2021. Handbook of wood chemistry and wood composites. https://doi.org/10.1201/b12487-5

Senila, L., Miclean, M., Senila, M., Roman, M., Roman, C., 2013. New analysis method of furfural obtained from wood applying an autohydrolysis pretreatment. Rom. Biotechnol. Lett. 18, 7947-7955.

Services, W.B. and T., 2006. Furfural chemicals and biofuels from agriculture, RIRDC Publication.

States, U., Toxicology, N., 1989. Furfural, in: IARC Monographs. p. 429.

Suxia, R., Haiyan, X., Jinling, Z., Shunqing, L., Xiaofeng, H., Tingzhou, L., 2012. Furfural production from rice husk using sulfuric acid and a solid acid catalyst through a two-stage process. Carbohydr. Res. 359, 1-6. https://doi.org/ 10.1016/j.carres.2012.07.006

TAPPI, 2011. Lignin in wood and pulp. T222 Om-02 17.

Uar, N.I., Wali, M., Tuharea, M.S., 2018. Sifat fisis kayu marsegu (Nauclea orientalis L) dari pulau buru, maluku. J. Agrohut 9, 110-116.

Wang, Q., Qi, W., Wang, W., Zhang, Y., Leksawasdi, N., Zhuang, X., Yu, Q., Yuan, Z., 2018. Production of furfural with high yields from corncob under extremely low water/solid ratios. Renew. Energy. https://doi.org/10.1016/j.renene. 2018.07.095

Winarti, C., Kurniati, M., Arif, A.B., Sasmitaloka, K.S., Nurfadila, 2018. Cellulose-based nanohydrogel from corncob with chemical crosslinking methods. IOP Conf. Ser. Earth Environ. Sci. 209. https://doi.org/10.1088/1755-1315/209/1/012043

Yulfa, D., Mayerni, R., Yusniwati, Y., 2019. Kualitas kimia serat beberapa klon rami asal sumatera barat. Agrotechnology Res. J. 3, 115. https://doi.org/ 10.20961/agrotechresj.v3i2.34761

Zhang, L., He, Y., Zhu, Y., Liu, Y., Wang, X., 2018. Camellia oleifera shell as an alternative feedstock for furfural production using a high surface acidity solid acid catalyst. Bioresour. Technol. 249, 536-541. https://doi.org/10.1016/j.biortech.2017.10.061

Zhang, L., Xi, G., Yu, K., Yu, H., Wang, X., 2017. Furfural production from biomass - derived carbohydrates and lignocellulosic residues via heterogeneous acid catalysts. Ind. Crop. Prod. 98, 68-75. https://doi.org/10.1016/j.indcrop.2017.01.014

Zhang, N., Li, S., Xiong, L., Hong, Y., Chen, Y., 2015. Cellulose-hemicellulose interaction in wood secondary cell-wall. Model. Simul. Mater. Sci. Eng. 23, $85010 . \quad$ https://doi.org/10.1088/09650393/23/8/085010

Zhao, Y.J., Li, C., 2018. Biosynthesis of plant triterpenoid saponins in microbial cell factories. J. Agric. Food Chem. 66, 12155-12165. https://doi.org/10.1021/acs.jafc.8b04657 